Pınar Dervişoğlu ${ }^{1}$, Mustafa Kösecik ${ }^{1}$, Mehmet Karacan ${ }^{2}$

${ }^{1}$ Sakarya Üniversitesi Tıp Fakültesi, Çocuk Kardiyoloji Bilim Dalı

${ }^{2}$ İstanbul Medipol Üniversitesi Tıp Fakültesi, Çocuk Kardiyoloji Bilim Dalı

$\ddot{O} Z$

Akut miyoperikardit perimyokardiyumun inflamasyonuyla seyreden tabloyu tanımlar. $\mathrm{Bu}$ tabloda perikardit genellikle, aynı etyolojik ajanları paylaşmaları nedeniyle, kardiyak troponin değerlerinde artışla kendini gösteren çeşitli derecelerde miyokard tutulumu ile birliktedir. Etyolojide enfeksiyöz, idyopatik ve immün nedenler sorumlu tutulur. En sık nedeni viral enfeksiyonlardır. Hastaların kliniğini myokard tutulumunun derecesi belirler. Burada özellikle yatarken artan göğüs ağrısı yakınması ile başvuran, elektrokardiyografisinde yaygın ST segment elevasyonu ve kardiyak enzim yüksekliği saptanan on altı yaşında bir myoperikardit olgusu sunuldu.

Anahtar Kelimeler: Göğüs ağrıs1, akut koroner sendrom, miyoperikardit

Türkçe Kısa Başlık: Myoperikardit

Yayın hakları Güncel Pediatri'ye aittir. 


\section{Myopericarditis Mimicking Acute Coronary Syndrome in Children}

Pınar Dervişoğlu ${ }^{1}$, Mustafa Kösecik ${ }^{1}$, Mehmet Karacan ${ }^{2}$

${ }^{1}$ Sakarya University Medical Faculty, Departmant Of Pediatric Cardiology

${ }^{2}$ Istanbul Medipol University Medical Faculty, Departmant Of Pediatric Cardiology

\section{ABSTRACT}

Acute myopericarditis defines an inflammatory syndrome which affects perimyocardium. In this clinical event, pericarditis is often accompanied by some degree of myocardial involvement, which is generally manifested by elevation of cardiac troponins. Main etiologic factors are infectious, idiopathic and immune mediated agents. The most common causes are viral infections. The clinical presentation of myopericarditis reflects the degree of myopericardial involvement. This article reports a myopericarditis event diagnosed at sixteen years old patient who presented with chest pain that increases when lying down and ST segment elevations and elevated cardiac enzymes.

Keywords: Chest pain, acute coronary syndrome, myopericarditis

İngilizce Kısa Başlık: Myopericarditis 


\section{Giriş}

Çocuklarda ve özellikle de ergenlerde göğüs ağrısı hastaneye başvuruların sık bir sebebi olmakla birlikte, nadiren altta yatan ciddi bir kardiyak patolojinin habercisidir. Kalp kökenli ağrılar tüm göğüs ağrıları içinde yaklaşık \%5-6 oranında görülür (1). Kardiyak nedenler arasında; doğuştan koroner arter anomalileri, Kawasaki hastalığı, taşiaritmiler, ventrikül çıkış yolu darlıkları, akut koroner sendrom ve miyoperikardit gibi enflamatuar hastalıklar sayılabilir. Akut miyoperikardit, perikardit ve miyokarditin birlikte görüldüğü inflamasyonla seyreden tabloyu tanımlar (2). Miyoperikardit idyopatik, infeksiyöz ve immünite aracılı olmak üzere üç ana etyolojik faktörle meydana gelebilir. Gelişmiş ülkelerde miyoperikarditin en sık nedeni viral infeksiyonlardır (3).

Akut perikardit tanısı tipik gögüs ağrısı, perikardiyal sürtünme sesi, elektrokardiyografi değişikliği (voltaj supresyonu, yaygin ST segment elevasyonu, PR depresyonu) ve ekokardiyografide perikardiyal efüzyonu içeren dört kriterden en az ikisinin varlığıyla konulur. Akut perikardit için tanı kriterleri sağlandığında myokardiyal komponentin varlığı araştırılır (4). Hastaların kliniği miyokard tutulumunun derecesine göre belirlenir. Başlıca semptomlar göğüs ağrısı, yorgunluk, egzersiz kapasitesinde azalma ve çarpıntıdır. Göğüs ağrısı en fazla görülen semptomdur ve iskemik gögüs ağrısından ayırt etmek zordur (5). Myoperikarditte troponin değerinde yükselme miyokardiyal inflamasyonun tutulumunun genişlemesiyle ilgilidir, ama akut koroner sendromun aksine kötü bir prognoz göstergesi değildir. Akut koroner sendrom ve miyoperikarditin tedavilerindeki farkl111klar nedeni ile miyoperikardit tanısının konulması son derece önemlidir. Bu yazıda göğüs ağrısı yakınması ile başvuran, akut koroner sendrom ile ayırıcı tanısı yapılan miyoperikardit olgusunu sunduk.

\section{Olgu}

On altı yaşındaki erkek hasta acil servise üç gündür olan göğüs ağrısı ve halsizlik yakınmasıyla başvurdu. Istirahat halinde izlenen, eforla ilişkili olmayan, yatmakla artan göğüs ağrısı tarifliyordu. Hastanın öyküsünden on gündür vücut geliştirme amacıyla protein tozu kullandığı öğrenildi. Fizik muayenesinde; Aksiller ateş:36.7 ${ }^{\circ} \mathrm{C}$, nabzı: 86/dakika DSS:20/dk idi. Sistem muayeneleri doğaldı. Elektrokardiyografisinde yaygın ST segment elevasyonu saptandı (Resim 1). 


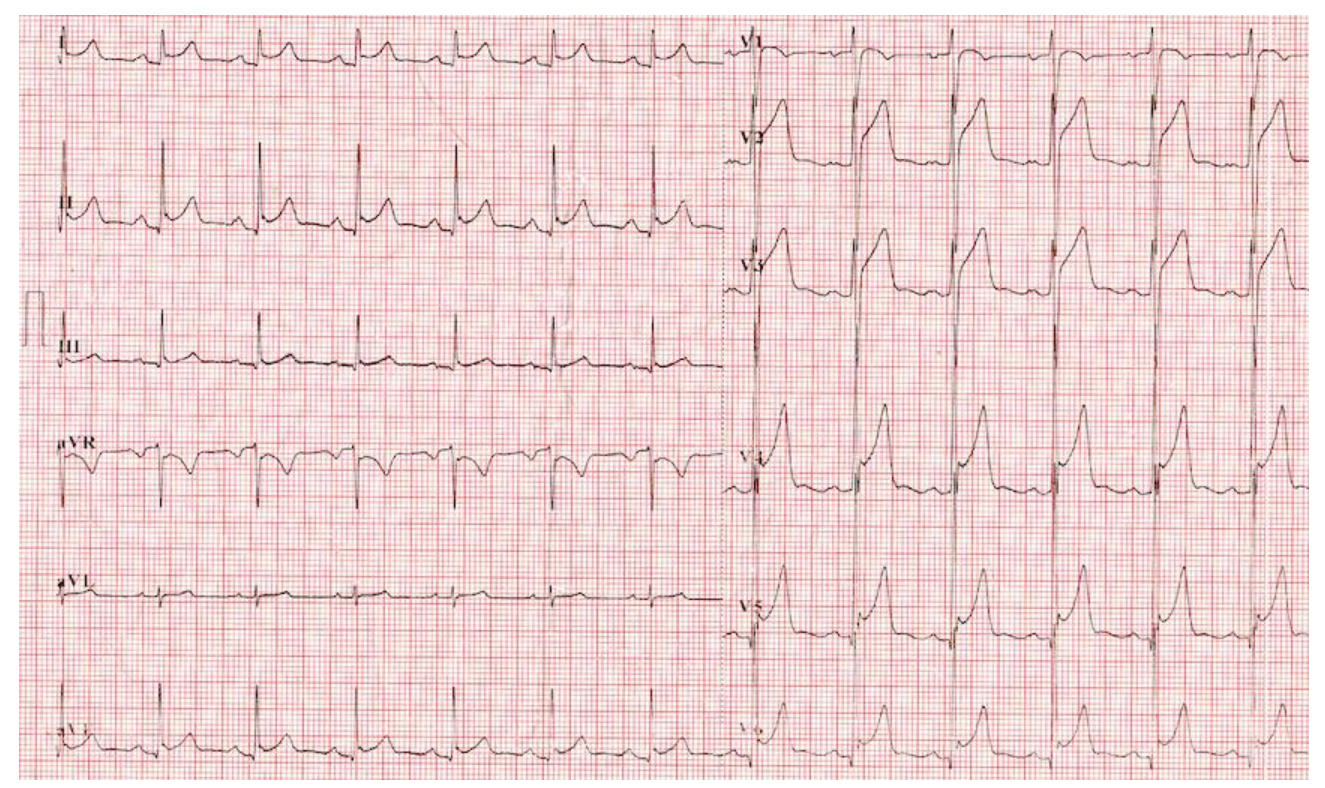

Resim 1. ST Değişiklikleri Görülen EKG Bulguları

Laboratuvar bulgularında; Hgb:13,7 g/dL, Hct:\%41,3 WBC:10.800/mm3, Plt:214.000/mm3, CRP: 72,1 $\mathrm{mg} / \mathrm{L}(\mathrm{N}<5 \mathrm{mg} / \mathrm{L})$, sedimentasyon:34 mm/sa idi. Kardiyak enzimlerinde yükselme mevcuttu. Troponin I düzeyi 11,48 ng/mL (0,01-0.06ng/mL), Miyoglobin:487 ng/mL (0-110 ng/mL), CK:615 U/L (38-174 U/L), CK-MB: 49 U/L (7-25 U/L) olan hasta akut koroner sendrom ve akut miyoperikardit ön tanılarıyla servisimize yatırıldı. Transtorasik ekokardiyografisinde sol ventrikül boyutu ve duvar hareketleri normaldi, perikardiyal sıvı veya belirgin kapak patolojisi yoktu. Kardiyak kateterizasyonda koroner arterleri ve ventrikülografisi normal saptandı (Resim 2).

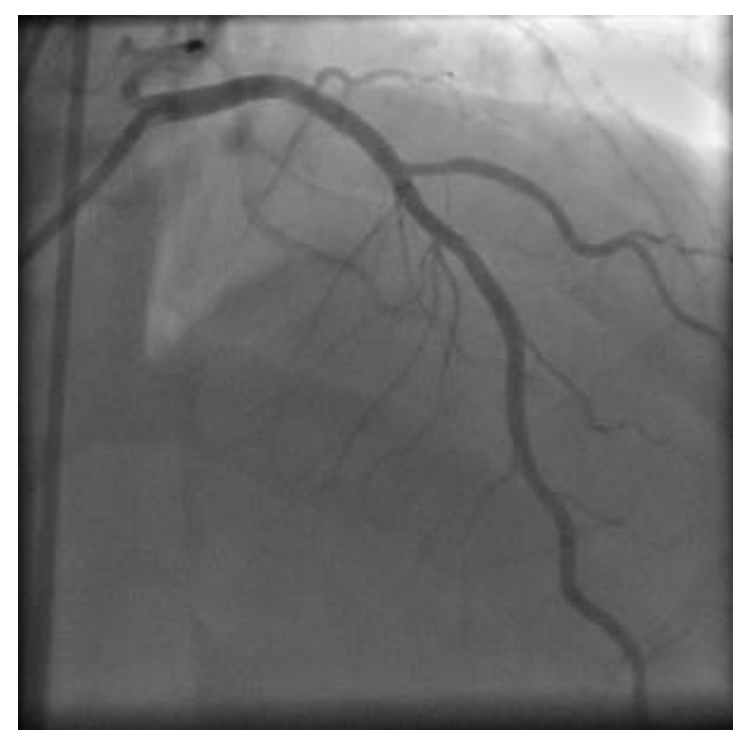

Resim 2. Hastanın Normal Angiografisi 
Miyoperikardit düşünülen hastaya ibuprofen başlandı. Takiplerinde troponin düzeyleri başlangiçta artış göstermesine rağmen, beş günlük izleminde $0,27 \mathrm{ng} / \mathrm{mL}$ 'ye kadar geriledi. Ayrıca hastanın şikayetleri ve EKG bulguları Troponin düzeylerindeki düşmeye paralel olarak geriledi. Hasta yatışının 7. gününde genel durumunun stabil seyretmesi, laboratuvar ve EKG bulgularının normale dönmesi üzerine taburcu edildi.

\section{Tartışma}

Göğüs ağrısı ve artmış troponin değerleri ile başvuran, kardiyak hastalık öyküsü olmayan adölesanlar klinisyenler için tanısal bir sorun teşkil edebilir. Akut koroner sendrom ve miyoperikardit tedavisi farklı olduğundan ayırıcı tanının yapılması son derece önemlidir. Sağlıklı çocuklarda miyokard enfarktüsü çok nadir olmasına rağmen uyuşturucu madde kullananlarda, koroner arter anomalilerinde, koroner anevrizmayla birlikte seyreden Kawasaki hastalarında, familyal hiperkolesterolemi ve koroner vazospazmda görülebilir. Çocuklarda koroner ateroskleroz için risk faktörü yok ise akut koroner sendrom nadirdir (6). Bizim olgumuz adölesandı ve akut koroner sendrom için risk faktörü yoktu. Öyküsünde ateş veya geçirilmiş üst solunum yolu enfeksiyonu yoktu, on gündür vücut geliştirme amacı ile protein tozu kullanımı öyküsü vardi. EKG de tüm prekordiyal derivasyonlarda yaygın ST elevasyonu vardı, kardiyak enzimleri yüksekti ve ekokardiyografik incelemesi normaldi. Akut koroner sendromu dışlamak amacı ile koroner anjiografi yapıldı ve normal olarak bulundu.

Akut perikardit tanısı tipik göğüs ağrısı, perikardiyal sürtünme sesi, EKG değişikliği (voltaj supresyonu, yaygın ST-segment elevasyonu, PR depresyonu ) ve EKO'da perikardiyal efüzyonu içeren dört kriterden en az ikisinin varlığıyla konulur. Perikardiyal efüzyon varlığı tanıyı destekler ancak yokluğu tanıyı ekarte ettirmez (4). Akut perikardit için tanı kriterleri sağlandığında, miyokardial komponentin varlığı açısından değerlendirme yapılır. Serum kardiyak enzim (CK-MB, Troponin) seviyelerinin yüksek bulunması, görüntüleme yöntemi ile kanıtlanmış (genellikle ekokardiyografi) yeni başlangıçlı, diğer başka nedenlere bağlı olmayan fokal veya diffüz sol ventrikül foksiyonlarında azalma miyoperikarditi düşündürür. C-reaktif protein gibi inflamatuar markırların artışı klinik şüpheyi doğrular $(7,8)$. 
Olgumuzda tipik göğüs ağrısı ve EKG'de yaygın ST segment elevasyonu varlığı akut perikardit tanısı için gerekli dört kriterden ikisini sağladığı için akut perikardit tanısı koydurdu. Ayrıca $\mathrm{C}$ reaktif protein ve eritrosit sedimentasyon hızı gibi inflamatuar markerların artmış olması da klinik şüpheyi güçlendirdi. Serum kardiyak enzimlerinden Troponin I, miyoglobin ve CK-MB 'nin yüksek olması, EKG' de yaygın ST segment elevasyonu varlı̆̆ kapasitesinde azalma olması miyokard tutulumunun eşlik ettiğini gösteren bulgulardı. Bu bulguların birlikteliği olgumuzda da miyoperikardit tanısı koymamızı sağladı.

Miyoperikardit tedavisinde ibuprofen yan etkilerinin az olması, koroner arter kan akımında olumlu etkisi ve geniş doz aralığı nedeni ile ilk tercih edilen antiinflamatuar ajanlardandır. (2) Biz de olgumuzda ibuprofen başladık, tedavinin üçüncü gününde gögüs ağrısı şikayeti düzeldi. Klinik bulguların düzelmesiyle korele olarak troponin I seviyesinde de azalma gözlendi.

Sonuç olarak göğüs ağrısı ve artmış troponin değerleri ile başvuran, öncesinde kardiyak hastalık öyküsü olmayan adölesanlar klinisyenler için tanısal bir sorun teşkil edebilir. Klinik ve laboratuvar bulguları benzer olan akut koroner sendrom ve myoperikardit ayırıcı tanısı tedavilerindeki farklılıklar nedeni ile önemlidir. 


\section{Kaynaklar}

1. Kane D, Fulton D, Saleeb S, Zhou J, Lock J, Geggel R. Needles in hay: chest pain as the presenting symptom in children with serious underlying cardiac pathology. Congenital Heart Disease 2010;5:366-73.

2. Imazio M, Cooper L. Management of myopericarditis. Expert Review Of Cardiovascular Therapy 2013;11:193-201.

3. Spodick DH. The pericardium: a comprehensive textbook. New York: Marcel Dekker; 1997. p. $114-25$

4. Friedman RA, Schowengerdt KO, Towbin JA. Myocarditis. In: Garson A, Bricker JT, Fisher DJ, et al, eds. The Science and Practice of Pediatric Cardiology. 2nd ed. Baltimore (MD): Williams \& Wilkins; 1998. p.1777-94.

5. Imazio, M., \& Trinchero, R. (n.d). Myopericarditis: Etiology, management, and prognosis. International Journal Of Cardiology 2008;127:17-26.

6. Schwartz M, Wellen S, Rome J, Ravishankar C, Natarajan S. Chest pain with elevated troponin assay in adolescents. Cardiology In The Young 2013;23:353-60.

7. Ozyurt A, Baykan A, Pamukcu O. Akut Miyo/Perikardit Tanısı Alan 28 Çocuk Hastanın Retrospektif Değerlendirilmesi. Turkiye Klinikleri J Med Sci 2013;33:1166-74.

8. Kobayashi D, Aggarwal S, Kheiwa A, Shah N. Myopericarditis in children: elevated troponin I level does not predict outcome. Pediatric Cardiology 2012;33:1040-5. 